\title{
On the Tightening and Loosening of Small Screw
}

\section{O園田 真也（工学院大学）小林 光男（工学院大学）福田 勝己（東京高専）}

Shinya SONODA : Kogakuin University, 1-24-2, Nishishinjyuku, Shinjyuku-ku, Tokyo, 163-8677 Mitsuo KOBAYASHI : Kogakuin University , 1-24-2, Nishishinjyuku, Shinjyuku-ku, Tokyo, 163-8677 Katsumi FUKUDA : Tokyo National College of Tech. ,1220-2, Kunugidamachi, Hachouji-city, Tokyo , 193-0997 Key wards : Machine element, , Thermal load, Tightening force, Tightening length Key words : Machine element, Small Screw, Tightening force, Tightening Torque, Torque control method

1.はじめに

ねじの締付けにおいて，適正な締付け力を与えることは 重要であるがそれを決定することは容易ではなく，小ねじ については更に困難で, 締付け力のばらつきも大きいとい われている ${ }^{1)}$ ，機械構造物及び精密機器などの締結には， 多くのねじが使用されているが，特に電気・電子系機器関 係には小ねじの使用が多い，また，小ねじの使用において は, 比較的安易な締結が行われ，機器の搬送中に生じる振 動，衝撃及び熱などによりねじのゆるみによる不具合を生 じ, 使用不能及び機能低下が問題になっている.しかし, 系統的な小ねじの締付けデータは少なく, 更なる研究が要 望されている，そこで前報 ${ }^{2)}$ ではM1 から M6 の乎び径を用 いてトルク法により乾燥状態の締付けを行い,トルク係数 について，標準偏差と呼び径の影響を実験的に検討した. 本報告は，最も簡便で多用されているトルク法により小ね じの締付けを行い，締付け特性の評価項目としてトルク係 数を求め, その大きさについて潤滑の影響も含めて実験的 に検討し，更にそのゆるみ特性を調べたものである.

\section{2. 締付け特性の評価}

締付け特性の評価として, トルク法のトルク係数とし, 簡単なボルト・ナット系の締結モデルについてその力学と 締付け管理方法の原理から, 締付けトルク $T_{f}$ と締付け力 $F_{f}$ の関係は, トルク係数 $K$, 呼び径 $d$ として次式とかける.

$$
\begin{aligned}
& T_{f}=K F_{f} d \\
& K=\left(P / \pi+\mu_{s} \cdot d_{2} \cdot \sec \alpha^{\prime}+\mu_{w} \cdot D_{w}\right) / 2 d
\end{aligned}
$$

ここで, $\mu_{s}$ : 永じ面摩擦係数, $\mu_{w}$ : 座面摩擦係数, $D_{w}$ : 座面における摩擦トルクの等価直径, $\mathrm{P}$ : ピッチ, $d_{2}$ : ね じの有効径， $\alpha$ : ねじ山のフランク角， $\alpha^{\prime}$ : ねじ山直角 断面におけるフランク角である. ただし，一般の締付け用 ねじのリード角 $\beta$ は， $35 \mathrm{deg}$ の小さい值であるので $\alpha \cdot$ の 代わりに $\alpha$ (通常 $30 \mathrm{deg}$ )を用いても誤差は僅かであり，実 際上問題はない. 従って, 式(1)において, トルク係数 $K$ が定まると, 締付けトルクによって締付け力を管理するこ とが出来る.

3. 実 験
図 1 に実験状態の概略を，図 2 及び表 1 にめねじ部の形 状・寸法を示す，圧縮型ロードセルに座金を介してトルク 表示付きレンチによりボルト・ナットで締付け，締付けト ルクと締付け軸力の関係を求める. 使用したトルク表示付 き締付けレンチは，市販の $0.1 \mathrm{Nm}, 0,5 \mathrm{Nm}, 1 \mathrm{Nm}$ の 3 種類で, ひずみゲージ変換式ロードセルからデジタル荷重計により 締付け軸力を求めている. また, 使用したねじは, M 1 ～M 6 の 6 種類で，鋼製の小ねじで，予めボルトは万能投影機 及び三針法により形状寸法を測定し，ナットは硫黄 $(60 \%)$ と黒鉛 $(40 \%)$ を混合し融解させ，めねじの鋳型からねじ山 の寸法形状を測定する，実験は，各呼び径に対して 20 本 の試料を用いて，各 1 本毎に 10 回の実験を行い合計 200 回の測定を行った。また, 潤滑状態は乾燥状態(接触面を ベンジンで洗浄し乾燥した状態)，ねじ部狳油状態 (ねじ面 にミシン油を塗布), 座面塗油状態(座面にミシン油を塗 布), ベアリング状態 (座面と被締結体の間にスラストベア リングを挿入)により，4種類の摩擦状態とした。

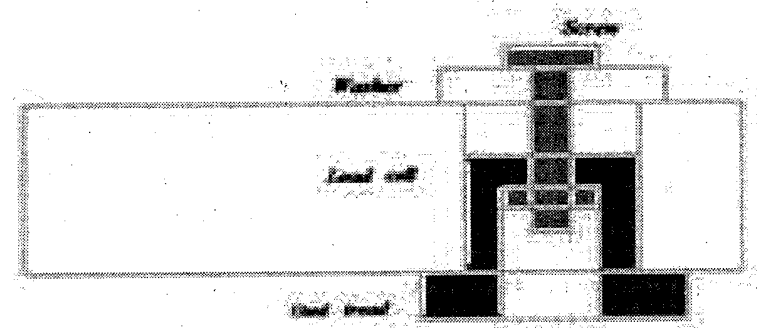

Fig. 1 Sectional view of experimental device

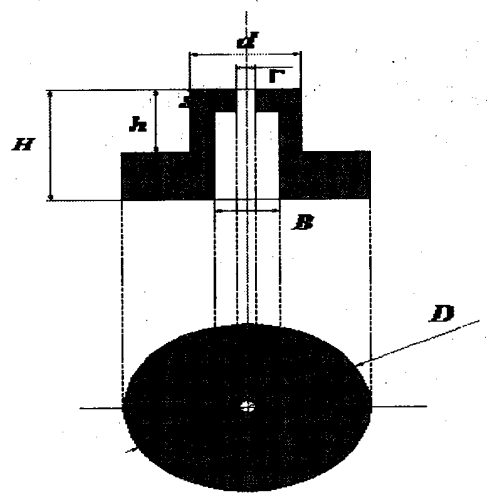

Fig. 2 Shape of nut part 
Table 1 dimensions of nut part (mm)

\begin{tabular}{|l|l|l|l|l|l|l|l|l|}
\hline & D & d & x & s & h & H & B & r \\
\hline M3 & 32 & 15 & 47 & 5 & 42 & 52 & 6.5 & 3.3 \\
\hline M4 & 32 & 15 & 47 & 5 & 42 & 52 & 8 & 4.2 \\
\hline M5 & 32 & 15 & 47 & 5 & 42 & 52 & 9.5 & 5.2 \\
\hline M6 & 32 & 15 & 47 & 5 & 42 & 52 & 11.5 & 6.2 \\
\hline
\end{tabular}

\section{4. 実験結果及び考察}

\section{1 小ねじの締付け試駚について}

各々の場合において，締付けトルクと締付け力の関係か らトルク係数を算出し，ヒストグラム及び正規分布曲線を 示す(合計度数は 200 ，トルク係数 $\mathrm{k}$ の級間は 0.05). 締付 けトルクと締付け軸力の関係は直線関係にあり, 各直線と も弾性域で, しかもトルク係数は各々一定值を示す.

図 3 は，呼びがM5 の実験例でトルク係数を求めヒスト グラムで表示した実験例で，小ねじの強度による違いを比 ベたものである，図 3 (a) は，強度が低い場合(熱処理な し)で，図 3 (b) は，強度が高い小ねじの場合(熱処理)であ る.図より，熱処理無しの場合はトルク係数のばらつきが 大きく，標準偏差及び四分偏差とも高く，熱処理小ねじは ばらつきが小さく四分偏差も小さい。 また，トルク係数の 平均值では熱処理無しの場合の方が大きく，熱処理小ねじ の場合は約 $50 \%$ 程度低く締付けトルクが小さくなる.

次に，ねじの利点でもある再利用の観点から検討してみ るため, 1 回目と 10 回目の締付けでのトルク係数のばら つきを調べたところ，熱処理小ねじの場合はばらつきの変 化は見られなかったが，熱処理無しの場合は 1 回目に比べ て 10 回目は大きくばらついている，以上のことから，締 付けを行なうと単純に熱処理無しの場合の方がばらつくと いう訳ではなく, 10 回という締付けの過程で締付け力の 低下が起こる事が同える．この原因として考えられる事は， ねじ面及び座面の変形にとる各面の摩擦の変化である.

\section{2 小ねじのゆるみ試験について}

図 5 は，振動によるねじのゆるみを調べる為に，振動試 験機の上に写真(試験機上の治具)の状態にねじ締結体を構 成し締付け力の減少挙動を調べたものである．図 6 は，振 動時間に対する小ねじの軸力挙動を示す．図よりM 5 及び M 6 は，初期ゆるみが大きく，その後は緩い低下を示すが， M 4 以下のサイズは, 締付け力を保てずにゆるんでいる.

限界締付け及び応力一定の場合ともに振動外力には耐え られず, 締付け力が 0 になっている. 熱処理無しの小ねじ は，熱処理無に比べて，ゆるみが大きいが，熱処理がある 場合の方が無に比べて使用効率が低いためである。

\section{5.まとめ}

（1）普段小ねじを締付ける際の締付け力は，小ねじの強度 の $10 \%$ 程度に満たなく，使用効率の検討が必要である.

（2）熱処理などの加工を施した強度が高い小ねじでないと

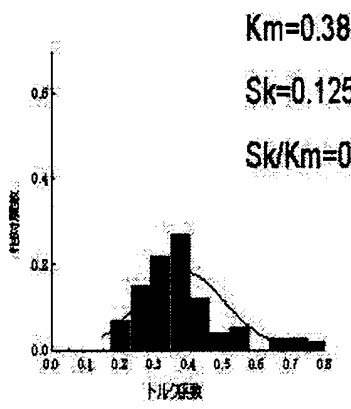

(a) Non heat treatment

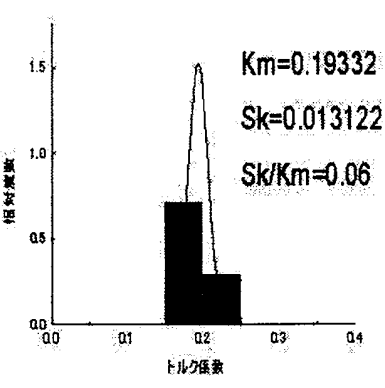

(b) heat treatment

Fig. 3 Influence of Strength and distribution on torque factor (case of M5)

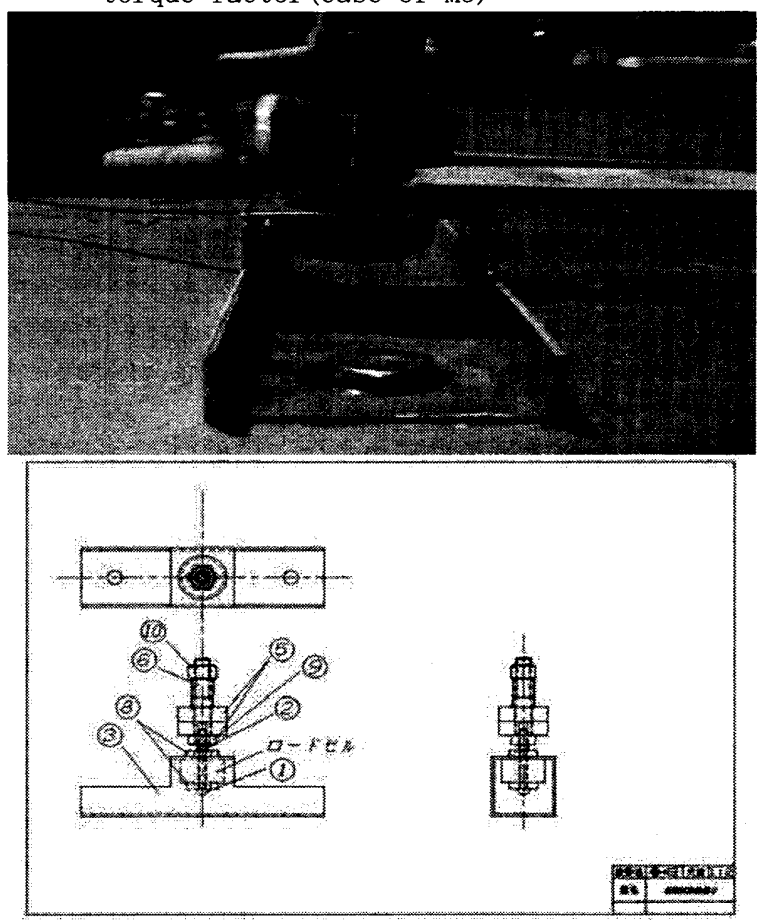

Fig. 5 Loosening test of small screw

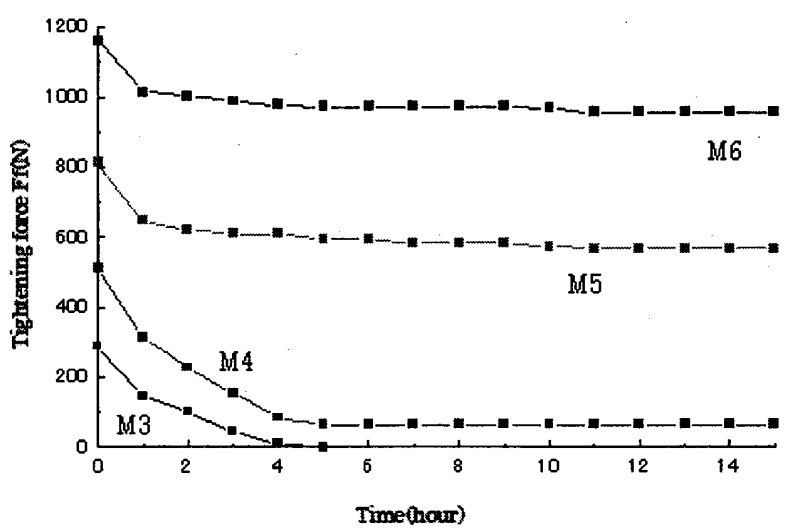

Fig. 6 Lower behavior of axial force by vibration

再利用にはあまり向いていない。

(3)サイズによる締付け力のばらつきへの影響は殆ど無い.

(4) ねじのサイズが大きいほうが高い締付け力を与えられ るためゆるみにくい.

（5）小ねじの強度に対して，使用効率が高いほうがゆるみ にくい. 